\section{IMPROVING THE STUDENT'S READING SKILL TROUGH SQ3R TECHNIQUE IN MTS AL-KHAIRIYAH}

\author{
Titi Widiawati', Ida Nuraida², Sisca Wulansari \\ Saputri3 \\ Universitas Banten Raya
}

Email: titiwidiawati@gmail.com

\begin{abstract}
Abstrak. Tujuan dari penelitian ini adalah untuk mengetahui apakah penerapan teknik SQ3R dapat meningkatkan pemahaman membaca siswa kelas delapan Mts Al-Khairiyah pada tahun akademik 2018/2019. Oleh karena itu, untuk mencapai tujuan tersebut, penulis melakukan penelitian tindakan. Penelitian ini dilakukan dalam dua siklus di mana setiap siklus memiliki 2 sesi. Data dianalisis dengan membandingkan hasil pre-test dan post-test. Hasil post-test menunjukkan peningkatan yang signifikan. Penelitian ini selanjutnya menunjukkan bahwa sebagian besar subjek memberikan respon positif bahwa teknik SQ3R berhasil diterapkan dalam meningkatkan pemahaman membaca subjek. Sebagai kesimpulan, penelitian tindakan kelas ini membuktikan bahwa teknik SQ3R dapat meningkatkan pemahaman membaca siswa kelas delapan Mts Al-Khairiyah pada tahun akademik 2018/2019.
\end{abstract}

Kata Kunci: Teknik SQ3R, keterampilan membaca, mengajar membaca
INTERFERENCE

Journal of

Language,

Literature, and

Linguistics

Submitted: January $15^{\text {th }}, 2020$

Accepted : February $19^{\text {th }}, 2020$

Abstract. The objectives of this research is to figure out whether or not the implementation of SQ3R technique can improve reading comprehension of the eighth grade students of Mts AlKhairiyah in academic year 2018/2019. Therefore, to achieve the objective, the writer conducted a action research. This research was conducted in two cycles where each cycle had 2 sessions. The data were analyzed by comparing the result of pre-test and post-test. The result post- test showed the significant improvement. This research furthermore showed that most of the subjects gave positive response that SQ3R technique was successfully applied in improving the subjects' reading comprehension. In conclusion, the present classroom action study proved that SQ3R technique could improve reading comprehension of the eighth grade students of Mts AlKhairiyah in academic year 2018/2019. 


\section{INTRODUCTION}

Reading is a physical and mental activity that aims to understand the text and gain the meaning of the text. When reading, our eyes will be fixed on the sentences and our brain will absorb the contents of the text and will store it in memory.

According to Burhan (2012) reading is a physic and mental activity to reveal the meaning of the written texts, while in that activity there is a process of knowing letters. It says a physic activity because the parts of the body, our eyes particularly, do it. According to Nunan (1991), reading in this view is basically a matter of decoding a series of written symbols into their aural equivalents in the quest for making sense of the text. He referred to this process as the 'bottom-up' view of reading. And it says mental activity because perception and memory as parts of thought are involved in it. He then concludes that the main goal of reading is a process of comprehending written texts. In line with Brown (2004), Celce-Murcia (2001) views reading as an interactive process. It involves a text, a reader, and a social context in which the reading process occurs. This implies that the reader's past experiences, language background, and cultural framework, as well as the reader's purpose for reading influence reader's interpretation about the text. Mujiyanto, et al. (51-53), explains the types of reading that must be mastered and developed by someone, especially in the academic field, as follows:

1. Intensive reading, which is a kind of reading done to gain an understanding of the script ideas from the basic idea to the explanatory ideas and from the global to the detailed. This type of reading is commonly called reading comprehension,

2. Critical reading, is the highest reading level. This is because well-read and wellunderstood reading ideas, commented on and analyzed for errors and flaws,

3. Fast reading, reading this type is done to get daily information quickly, such as news and major reports on newspapers or magazines,

4. Read appreciative and aesthetic, which reads related to the guidance of appreciative attitude or appreciation of the values of beauty and psychology, reading techniques, is the type of reading that emphasizes the truth of reading and accuracy of intonation and pause

Adding the above opinion, another expert Harmer (2007) says that the reading is useful for language acquisition. Provided that students more or less understand what they read, the more they read, the better they get at it. Reading comprehension is important in students' life, including those who are going to pursue their studies at higher education, since they will have a lot of readings to do. Therefore to assist students in their reading comprehension phase and to know whether comprehension is taking place it is suggested to know what is in their brain when they read and the strategic they apply in their reading such as how they plan, arrange and evaluate their own reading. (Leonora Saantje Tamaela, 2018). In conclusion, reading comprehension can be adopted by the teacher and applied in the reading class in the school. Teacher should consider the upper level as the high achievers while the lower level as the low achiever in the class. SQ3R is a five-step 
strategy for reading and taking notes from chapter in a textbook. Each letter stands for one step i SQ3R is a five-step strategy for reading and taking notes from chapter in a textbook. Each letter stands for one step in the strategy. Using SQ3R will help you to understand what you read and to prepare a written record of what you learned.

A well known method for reading and studying textbook material is called the SQ3R method (developed by Francis P. Robinson). It is designed to help students understand and retain textbook material by using a system of series of steps to guide them as they read and study. They are five steps to be followed: Step 1: Survey. Surveying brings to mind what you already know about the topic of a chapter and prepares you for learning more. Step 2: Question. Textbooks are organized so that a large body of information is broken down into smaller units, each with its own title or heading. Step 3: Read. Read the information that follow each heading to find the answer to each question you formed. As you do this, you may decide you need to change a question or turn it into several questions to be answered.

The Advantages of using $\mathrm{SQ}_{3} \mathrm{R}$ Technique, SQ3R as a reading technique has some advantages to in crease student' reading comprehension. By using SQ3R technique, students can monitor or measure how far their reading comprehension is on the text (Rahyana, T., 2016; Yuliyanti, I., 2017; Syahfutra, W., 2010; Anjuni, G. R., \& Cahyadi, R., 2019).

\section{RESEARCH METHOD}

In this research, the writer used qualitative research design to implement the action research. The writer conducted classroom action research (CAR). The action research is supported by the data, in this case the result of the students' test. The main of qualitative research is searching the information about the improvement of students' in reading skills through $\mathrm{SQ}_{3} \mathrm{R}$ Techniques and quantitative research had support the qualitative data.

Classroom Action Research is a tool used to help teachers to improved teaching practices by doing reflective processes in order to find solution of teaching problems in the class. It emphasizes at the improvement of educational practical and process in learn. The writer was conducted at MTS Al Khairiyah, located on JIn.raya ciruas, Serang City, on 14 april_14 may 2019 and took class VIII as the subject of the research. The subject of this research are the students of the first semester of VIII. The class consists of 30 students in the academic year 2018/2019. It is because the students in class VIII. have difficulties and problem in comprehending narrative text. , the writer purpose to improve students' reading skills.

\section{RESULT AND DISCUSSION}

Based on the preliminary observation in the beginning of the research it was found that there were many problems have arose during the activities of reading in the classroom. Students were having difficulties The implementation of the research in each cycle is described in following section:

Cycle 1: The process of cycle 1 is as follows: Planning, Before implementing the action, the writer did observation and gave a pre-test to the students. The test 
was aimed to know the prior of the students" ability in reading comprehension. Having identified the students" problems, the indicators and the cause of those problems, the writer implemented the in understanding the research to improve students reading comprehension through SQ3R technique. Action, The writer carried out the action of cycle one in three meeting and one meeting for doing posttest. The activities of that research were presenting the material, explaining the way how to comprehend such text effectively by using SQ3R technique, doing an exercise, discussing the result of the students" work, and then reflecting what the Observation, Observing the action is really important to do because it can be used as one of the indicators to know the students" progress. In this case the writer as a researcher and a writer and the collaborator as an observer did both of them during the implementation of the action while the students were doing their activities. By observing the teaching and learning process in the first cycle, the writer knew the effectiveness of SQ3R technique in teaching reading comprehension. Reflection, After doing the first cycle of action research about improving students" reading comprehension through SQ3R technique in the class, there are some strengths and weaknesses which are found.

Cycle 2: Planning, Based on the weaknesses which were found in the first cycle, the writer revised the following plans. The writer focused on those indicators which had not reached the target yet. Here, the writer would give more explanation about that to solve it and gave more exercise to them.

The writer would implement pairs work to the students in order to make them more focused with their partner and were not noisy. The writer would tell the systematically of using SQ3R technique first until they really understood first before beginning the lesson. The writer, then, prepared important things to conduct cycle 2 as follows: The time allotment. The time allotment in each meeting was 40 to 80 minutes. There were three meeting in cycle two out of the post-test. Teaching Material. In order to make cycle run well, the researcher prepared some important teaching materials to support the implementation of SQ3R technique which were focused on the understanding and guessing the meaning of unfamiliar words and identifying the use of reference. The writer gave a clear explanation, more models and exercises related to those indicators. The teaching media used were students" worksheet and interesting presentation. Action. It was Tuesday, may $9^{\text {th }} 2019$ the writer entered at classroom at 09.15 a.m. When the writer came into the classroom, most of the students had come. They sat on their seats and chatted with the friends next to them. It was different from what happened in the first cycle that the students were not ready to study when the teacher arrived. The conversation stopped when the researcher stood in front of the class and greeted them. They answered the greeting loudly. It showed their motivation to join the class Observation, In this cycle, the observation process was carried out during the implementation of the action. In general, the teaching- learning process had changed better than the first cycle. The first meeting of the second cycle was held on Tuesday. Tuesday was a hard day for the students because they had an additional lesson in the morning and physic for the next two periods. English was held in the third period. It meant that the students had used almost of all their 
energy. Usually, they only wanted to have fun or relaxed. That was why, every time they had the fourth period on Tuesday they always be unmotivated or busy with their own activity.

\section{The Students' average score of Post-test 2}

\begin{tabular}{clc}
\hline No & Statement & Score \\
\hline 1. & Highest score & 96,7 \\
\hline 2. & Lowest score & 56,7 \\
\hline 3. & Average score & 80,06 \\
\hline
\end{tabular}

There were five reading comprehension indicators which were analyzed. They were the ability to: find out the main idea of a text, find detail information from the text, understand and guess the meaning of unfamiliar words, identify the use of reference and find out impliedinformation from the text. The result of the analysis could be seen in table below:

Post-test 2 score of reading elements

\begin{tabular}{llc}
\hline No. & \multicolumn{1}{c}{ Indicators } & Score \\
\hline 1. & Finding main idea & 78,5 \\
\hline 2. & Finding details information & 83,9 \\
\hline 3. & Understanding unfamiliar words & 74,7 \\
\hline 4. & $\begin{array}{l}\text { Understanding the use of } \\
\text { reference }\end{array}$ \\
\hline 5. & Finding implied meaning & \\
\hline
\end{tabular}

Based on the tables above, it could be concluded that the students the students had significant improvement compared with the previous cycle. Besides, it could be seen that all of the aspect of reading comprehension's score were able to reach the standard(KKM).

Reflection. After doing the second cycle of action research about improving students" reading comprehension through SQ3R technique in the class, there are some strengths. The strengths are shown as follows: The strengths of cycle 2: The strength in cycle two includes some points arising from the cycle one. They are the improvement of reading comprehension achievement (finding $d$ identifying the use of reference, and finding implied information), the improvement of students" 
motivation in reading, and the students" involvement in reading class as well as the class management (the class situation is more conducive, active and organized than before). The strengths in Reading: There is an improvement in students" reading comprehension achievement. All of the indicators of reading comprehension can reach the KKM (71). Besides, there are some indicators which their scores could reach more than the KKM. The most significant indicators of reading comprehension which improved are finding the main idea, finding detail information, and finding implied information of the text. Those can be shown from the mean score of each indicator which improved such as: the ability of finding the main idea increased from 66.1 up to 78.5 ; the ability of finding detail information increased from 56.45 up to 83.9 ; the ability of understanding the meaning of unfamiliar words increased from 51.61 up to 7.47; the ability of identifying the use of reference increased from 44.62 up to 72.00 , and 71.0 up to 78.5 for the ability of finding implied information.

Besides, the students" average scores improved from the 60.6 (pretest mean score) to 80.06 (post-test 2 score). The strengths in Teaching learning Activity: The students" motivation and involvement in the class improved because the writer also implemented the small group discussion and this multi-step plan of SQ3R technique which is combined before, during, and after reading activities help students become actively involved in reading. The SQ3R technique can help the students to set study goals so they can read or study effectively.

\section{Discussion}

Having analyzed the data in cycle 2, the researcher found several findings to answer the problems of the research. There are two major points in the research findings in cycle 2 related to the improvements of students" reading comprehension, students" reading achievement, andreading class condition.

The findings of the study showed that the use of SQ3R technique improves students" reading comprehension. Their ability was improved from cycle to cycle. In fact, they did know how to comprehend such text and also they had many difficulties in comprehending text, but they could implement SQ3R technique to comprehend such text effectively in post- test. Besides, they could minimize the mistakes they had before. The comparison of average scores of each indicators of reading comprehension between pretest and post-test 1 and post-test 2 can be shown in the table below.

The Comparison of Average Score of Each Reading Elements of Pre-test, Post-test 1, and Post-test 2

\begin{tabular}{ccccc}
\hline No & $\begin{array}{c}\text { The indicator of reading } \\
\text { comprehension }\end{array}$ & Pretest & Post test 1 & Post test 2 \\
\hline 1. & Finding main idea & 66,13 & 83,93 & 78,5 \\
\hline 2 & $\begin{array}{c}\text { Finding detail } \\
\text { Information }\end{array}$ & 56,45 & 83,93 & 83,93 \\
\hline 3 & $\begin{array}{c}\text { Understanding } \\
\text { unfamiliar words }\end{array}$ & 51,61 & 70,38 & 74,7 \\
\hline
\end{tabular}




\begin{tabular}{ccccc}
\hline 4 & $\begin{array}{c}\text { Identifying the use of } \\
\text { reference }\end{array}$ & 44,62 & 47,02 & 72,00 \\
\hline 5 & $\begin{array}{c}\text { Finding implied } \\
\text { information }\end{array}$ & 70.9 & 77,98 & 78,5 \\
\hline
\end{tabular}

The improvement of the students" reading comprehension score could be analyzed from the result of pre-test and post-test scores. Pre-test was conducted before the action while post-test was taken after each cycle. The students" reading comprehension score was improved after the implementation of SQ3R technique in teaching reading comprehension. The improvement of students" reading comprehension achievement can be seen in table below.

The Comparison of Average Score from Pre-test, Post-test 1, and Post-test 2

\begin{tabular}{lllll}
\hline No, & Statement & Pretest & Posttest 1 & Post-test 2 \\
\hline 1. & The highest score & 76,7 & 87,00 & 96,7 \\
\hline 2. & The lowest score & 5.00 & 60.00 & 5.67 \\
\hline 3. & The mean score & 60,01 & 75,00 & 80,06 \\
\hline
\end{tabular}

The findings of class situation on teaching and learning process when implementing SQ3R technique showed that the reading class situation was more alive. The students were motivated in joining the lesson. It was no longer a teacher centered process. They were active in reading activity, discussing and expressing ideas. They were active to discuss with their partner.

The findings of teaching and learning process showed that the teacher was more innovative and used certain technique in her teaching. Besides, she was also active to guide the students in doing their task and motivate them to be active. Those helped the students to improve their reading comprehension.

\section{CONCLUSION}

Based on the result of the study, it can be concluded that the learning by using SQ3R method can improve learning outcomes and reading comprehension ability of English. With the application of the SQ3R method in teaching and learning activities provides several benefits: students can process knowledge that is meaningful and useful, students have a very positive attitude that continues grow as long as they need, students develop more skills including solving problems, day, logic, and the ability to distinguish cause and effect relationship.

\section{REFERENCES}

Anjuni, G. R., \& Cahyadi, R. (2019). Improving Students'reading Comprehension Through Sq3r (Survey, Question, Read, Recite And Review) Technique. Project (Professional Journal of English Education), 2(1), 1-6. 
Burhan. (2012). Penilaian dalam Pengajaran Bahasa dan Sastra. Yogyakarta: BPFE. Brown, H.D. (2004). Teaching Language Assessment Principles and Classroom Practices. New York: Pearson Education, Inc

Celce-Murcia, M. (2001). Teaching English as a Second and Foreign Language (3rd Ed). Boston: Heinle \& Heinle Thomson Learning, Inc.

Harmer, J. (2007). How to teach English. England: Longman Pearson.

Leonora Saantje Tamaela, (2018). EFL Students' Awareness of Strategic Reading Processes: Facts and Challenges. The Asian EFL Journal ,10(20), 116-12

Nunan, D. (1991). Language Teaching Methodology. Hertfordshire: Prentice Hall International.

Rahyana, T. (2016). The Effect Of Sq3r Techniquetoward Students'reading Comprehension Of Descriptive Text At Grade Seventh Students Of Smp Negeri 02 Pagarantapah Darussalam. Jurnal Ilmiah Mahasiswa FKIP Prodi Bahasa Inggris, 2(1).

Syahfutra, W. (2010). The Effect Of Sq3r Method Toward Reading Achievement Of The Second Year Students At MAN 1 Pekanbaru (Doctoral dissertation, Universitas Islam Negeri Sultan Syarif Kasim Riau).

Yuliyanti, I. (2017). The Use Of Sq3r And Mapping Strategies To Improve Students'reading Comprehension At The Tenth Grade Students Of Man Salatiga In The Academic Year 2017/2018. English Education, 113(13), 123. 